\title{
Expression of manganese superoxide dismutase in rat blood, heart and brain during induced systemic hypoxia
}

\author{
Septelia I. Wanandi, ${ }^{1}$ Syarifah Dewi, ${ }^{1,2}$ Sri W. A. Jusman ${ }^{1}$ Mohamad Sadikin ${ }^{1}$ \\ ${ }^{1}$ Department of Biochemistry and Molecular Biology, Faculty of Medicine Universitas Indonesia, Jakarta \\ ${ }^{2}$ Master Program in Biomedical Sciences, Faculty of Medicine Universitas Indonesia, Jakarta
}

\begin{abstract}
Abstrak
Latar belakang: Hipoksia mengakibatkan peningkatan ROS. Hingga saat ini, belum banyak diketahui mengenai peran MnSOD - enzim antioksidan endogen utama - pada respons adaptasi sel terhadap hipoksia. Penelitian ini bertujuan menganalisis ekspresi mRNA dan aktivitas spesifik MnSOD pada darah, jantung dan otak tikus yang diinduksi hipoksia sistemik.
\end{abstract}

Metode: 25 ekor tikus Sprague Dawley diinduksi hipoksia sistemik di dalam ruang hipoksia (8-10\% O2) selama 0, 1, 7, 14 atau 21 hari. Ekspresi relatif mRNA MnSOD dianalisis menggunakan Real Time RT-PCR. Aktivitas spesifik MnSOD diukur dengan metode inhibisi xantin oksidase.

Hasil: Ekspresi relatif mRNA MnSOD pada darah dan jantung tikus menurun selama fase awal induksi hipoksia sistemik (hari ke 1) dan meningkat setelah hari ke 7, sedangkan ekspresi mRNA pada otak meningkat sejak hari ke 1 dan mencapai kadar maksimum pada hari ke 7. Hasil pengukuran aktivitas spesifik MnSOD selama awal induksi hipoksia sistemik menyerupai hasil ekspresi mRNA. Pada kondisi hipoksia yang sangat lanjut (hari ke 21), aktivitas spesifik MnSOD pada darah, jantung dan otak menurun secara signifikan. Ekspresi mRNA MnSOD pada ketiga jaringan tersebut selama hari ke 0-14 induksi hipoksia sistemik berkorelasi positif dengan aktivitas spesifiknya. Selain itu, ekspresi mRNA dan aktivitas spesifik MnSOD pada jantung berkorelasi kuat dengan hasil pada darah.

Kesimpulan: Ekspresi MnSOD pada fase awal dan lanjut induksi hipoksia sistemik mengalami regulasi yang berbeda. Ekspresi MnSOD pada otak berbeda dengan pada darah dan jantung, menunjukkan bahwa jaringan otak dapat lebih bertahan pada induksi hipoksia sistemik dibandingkan jantung dan darah. Pengukuran ekspresi MnSOD di dalam darah dapat digunakan untuk menggambarkan ekspresinya di dalam jantung pada keadaan hipoksia sistemik. (Med J Indones 2011; 20:27-33)

\begin{abstract}
Background: Hypoxia results in an increased generation of ROS. Until now, little is known about the role of MnSOD - a major endogenous antioxidant enzyme - on the cell adaptation response against hypoxia. The aim of this study was to determine the MnSOD mRNA expression and levels of specific activity in blood, heart and brain of rats during induced systemic hypoxia.

Methods: Twenty-five male Sprague Dawley rats were subjected to systemic hypoxia in an hypoxic chamber (at $8-10 \%$ O2) for $0,1,7,14$ and 21 days, respectively. The mRNA relative expression of MnSOD was analyzed using Real Time RT-PCR. MnSOD specific activity was determined using xanthine oxidase inhibition assay.

Results: The MnSOD mRNA relative expression in rat blood and heart was decreased during early induced systemic hypoxia (day 1) and increased as hypoxia continued, whereas the mRNA expression in brain was increased since day 1 and reached its maximum level at day 7 . The result of MnSOD specific activity during early systemic hypoxia was similar to the mRNA expression. Under very late hypoxic condition (day 21), MnSOD specific activity in blood, heart and brain was significantly decreased. We demonstrate a positive correlation between MnSOD mRNA expression and specific activity in these 3 tissues during day 0-14 of induced systemic hypoxia. Furthermore, mRNA expression and specific activity levels in heart strongly correlate with those in blood.

Conclusion: The MnSOD expression at early and late phases of induced systemic hypoxia is distinctly regulated. The MnSOD expression in brain differs from that in blood and heart revealing that brain tissue can possibly survive better from induced systemic hypoxia than heart and blood. The determination of MnSOD expression in blood can be used to describe its expression in heart under systemic hypoxic condition. (Med J Indones 2011; 20:27-33)
\end{abstract}

Key words: MnSOD, mRNA expression, ROS, specific activity, systemic hypoxia

Nowadays, the pattern of morbidity and mortality in Indonesia has shifted from infectious to degenerative diseases, such as cardio- and cerebrovascular diseases and cancer. Almost all risk factors for those diseases could induce hypoxic condition, indicating the involvement of hypoxia in pathogenesis of the degenerative diseases. ${ }^{1}$

Correspondence email to: septelia@gmail.com
Hypoxia is a pathological condition in which the body as a whole or region of the body is deprived of adequate oxygen supply. This condition threatens life of cells or organisms. The ability to maintain oxygen homeostasis is essential for the survival of all aerobic species. Oxygen homeostasis mechanisms can occur at systemic level and cellular level, such as by oxygen sensing. At 
systemic level, low oxygen could stimulate heart rate, peripheral vasodilatation and hyperventilation, whereas at cellular level, anaerobic metabolic pathways would be activated. ${ }^{2,3}$

One of the cellular oxygen sensing reactions in hypoxia is the increased level of hypoxia-inducible factor- $1 \alpha$ (HIF-1). HIF-1 $\alpha$ is a ubiquitous intracellular protein that is degraded by prolyl hydroxylase right after its biosynthesis in normoxic condition. Stabilized HIF-1 $\alpha$ joins HIF- $1 \beta$ to form HIF-1 transcription factor which interacts with HRE (HIF-1 response element) and regulates the transcription of essential genes for the adaptation responses to hypoxia. ${ }^{4-6}$

Hypoxia results in an increased generation of reactive oxygen species (ROS), such as superoxide anion radical $\left(\mathrm{O}_{2}^{\circ}\right)$ and hydrogen peroxide $\left(\mathrm{H}_{2} \mathrm{O}_{2}\right)$ in mitochondria. Free radicals are molecules that have at least one unpaired electron and thus are very reactive. The term ROS also includes reactive oxygen species which are chemically not radicals, e.g., hydrogen peroxide. Under hypoxic condition, the consumption of oxygen at cytochrome c oxidase level (complex IV of the mitochondrial electron transport chain) is lower than under normoxic conditions and electrons accumulate at the preceding complex III. Such an accumulation leads to an increased generation of ROS at complex $\mathrm{III}^{7}$ or on the transport between the two complexes by cytochrome C. In hypoxia, ROS also participate in signal transduction pathways inducing the stabilization of HIF-1 $\alpha$. Moreover, pro-oxidant treatment in normoxic cells can activate genes that induce hypoxia. ${ }^{3,8}$

Superoxide dismutase (SOD) is one of the antioxidant enzymes that could protect cells from oxidative damage. This enzyme converts very reactive superoxide anion radicals $\left(\mathrm{O}_{2}^{-*}\right)$ to less reactive hydrogen peroxide $\left(\mathrm{H}_{2} \mathrm{O}_{2}\right)$. Among the three isoforms of SOD, manganese superoxide dismutase (MnSOD) is the major antioxidant enzyme in mitochondria that scavenges superoxide radicals generated by the electron transport chain in mitochondria. ${ }^{7}$ Decreasing the MnSOD level could elevate ROS levels in mitochondria and lead to oxidative stress including oxidative the damage of biomacromolecules, such as proteins, lipids and DNA. ${ }^{9}$

Many studies have explained the important role of MnSOD in the prevention of oxidative stress. ${ }^{10,11}$ However, little is known about the expression of MnSOD during systemic hypoxic conditions, particularly in the essential tissues, such as brain, heart and blood. In the present study, mRNA expression and specific activity of MnSOD were analyzed. The information about differential MnSOD expression in various tissues during induced systemic hypoxia would open the new concept of localized adaptation response as antioxidant protection.

\section{METHODS}

This was an experimental study carried out at Biochemistry and Molecular Biology Laboratory, Faculty of Medicine University of Indonesia. All procedures were approved by the Ethical Committee of Research Center and Health Development, Ministry of Health Republic of Indonesia (BALITBANGKES RI; No. LB.03.02/ $\mathrm{KE} / 1347 / 2008$ ).

\section{Systemic hypoxia induction}

Twenty-five male Sprague Dawley rats (6-8 weeks old; body weight $150-200 \mathrm{~g}$ at entry into protocol) were randomly divided into 5 groups ( $\mathrm{n}=5$ per group). Rats were subjected to systemic hypoxia by placing them into a normobaric hypoxic chamber treated with $8-10 \%$ of $\mathrm{O}_{2}$ for 0 (control rats without hypoxia), 1, 7, 14 and 21 days, respectively. The hypoxic chamber (kindly provided by Dr. F. Ferdinal) was designed as previously described by Corno et al. ${ }^{12}$ All rats had free access to water and standard rat chow. Water and food consumption was assessed every 2 days.

\section{Isolation of total RNA and protein}

After hypoxic treatment, rats were sacrificed with ether anaesthesia. Rat blood was immediately collected from the heart for blood gas analysis. Subsequently, brain and heart tissues were rapidly excised. Samples from blood, heart and brain were used for the analysis of mRNA expression and specific activity of MnSOD. All excision procedures were executed in the hypoxic chamber.

Whole blood $(200 \mu \mathrm{l})$ was added into $600 \mu \mathrm{l}$ of Red Blood Cell Lysis Solution ${ }^{\circledR}$ (Promega). The mixture was incubated for 10 minutes at room temperature and centrifuged at $16000 \mathrm{rpm}$ for 20 seconds. The white pellet containing leucocytes was collected and kept at $-80^{\circ} \mathrm{C}$ before use. Total RNA was extracted from leucocytes and tissue samples (100 mg) using Tripure RNA Isolation Kit $\mathbb{R}$ (Roche) and was kept at $-80^{\circ} \mathrm{C}$ before use. The isolation of total protein from leucocytes and tissue samples was performed as previously described by Hardiany et al. ${ }^{13}$

\section{Analysis of MnSOD mRNA relative expression using Real Time RT-PCR}

Total RNA ( $300 \mathrm{ng})$ was amplified using iScript One Step RT-PCR Kit with SYBR Green ${ }^{\circledR}$ (BioRad). cDNA synthesis and PCR amplification were carried out in the same tube. 
Reaction protocol was as follows: cDNA synthesis for 10 minutes at $50^{\circ} \mathrm{C}$; inactivation of reverse transcriptase for 5 minutes at $95^{\circ} \mathrm{C}$; PCR cycles (40 cycles) for 10 seconds at $95^{\circ} \mathrm{C}, 30$ seconds at $59^{\circ} \mathrm{C}$ (after optimalization), 30 seconds at $72^{\circ} \mathrm{C}$; melting curve analysis for 1 minute at $95^{\circ} \mathrm{C}, 1$ minute at $55^{\circ} \mathrm{C} ; 10$ seconds at $55^{\circ} \mathrm{C}(80$ cycles increasing $0.5^{\circ} \mathrm{C}$ each cycle). Primers were designed according to NCBI gene bank data: NM_017051 (for MnSOD) and NM_031144 (for $\beta$-actin as a reference gene) using Primer 3 program \& Primer Analysis software. Primer sequences used to generate cDNA for MnSOD (178 bp) are: 5'- AACGTCACCGAGGAGAAGTA 3' (forward); 5' - TGATAGCCTCCAGCAACTCT - 3' (reverse) and those used to generate cDNA for $\beta$-actin (174 bp) are: 5'- CACTGGCATTGTGATGGACT - 3' (forward); 5'- CTCTCAGCTGTGGTGGTGAA - 3' (reverse). Amplification procedures for the $\beta$-actin gene were the same as for the MnSOD gene. Aqua bidest was used as a negative control (NTC) to reduce false positive results. The level of mRNA expression of treated groups was relatively determined using PfaffI formula and normalized to the control group (as a calibrator with expression level of 1 ).

\section{Analysis of MnSOD specific activity}

SOD activity was biochemically determined using xanthine oxidase inhibition assay, as previously described. ${ }^{13}$ To inhibit the $\mathrm{Cu} / \mathrm{ZnSOD}$, prior to addition of xanthine oxidase, natrium cyanide $(5 \mathrm{mM})$ was first added into each sample and incubated for 5 minutes in room temperature. Kinetic of enzyme activity was measured using spectrophotometer at $505 \mathrm{~nm}$ after 30 seconds and 3 minutes and calculated as a percentage inhibition of the samples plotted to the standard curve. The specific activity of MnSOD enzyme was calculated as enzyme activity (in Unit) per mg protein. Protein concentration was measured using spectrophotometer at $280 \mathrm{~nm}$ and plotted to the BSA (Bovine Serum Albumin) standard curve. Specific activity of MnSOD in rat blood, heart and brain are expressed as Unit/gram protein, and compared by using t-test.

\section{RESULTS}

Analysis of MnSOD mRNA expression using Real Time RT-PCR was first optimized for the primers' specificity. As shown in Figure 1, there was merely a single peak in the melting curve and a single band in the electrophoresis of cDNA product of MnSOD as well as $\beta$-actin. This indicates that the primers designed in this study for both genes could generate the specific cDNA products and there were no primer dimers present.

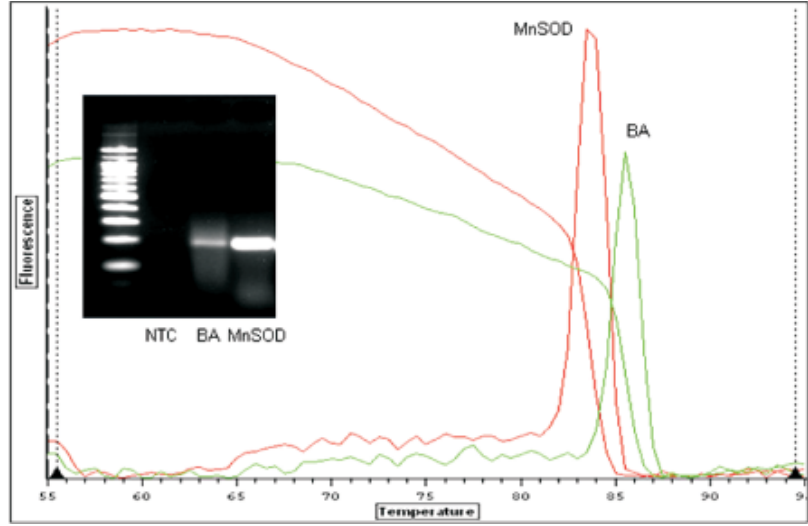

Figure 1. Melting curve of MnSOD and $\beta$-actin cDNA produced by Real Time RT-PCR.

Insert: Electrophoresis on 2\% agarose gel for MnSOD cDNA (178 bp) and $\beta$-actin cDNA (174 bp). NTC (Non-template control) is a negative control: no cDNA product visible for NTC.

Figure 2 shows that MnSOD mRNA relative expression in rat blood and heart was decreased during early induced systemic hypoxia (day 1) and continuously increased after 7 days of systemic hypoxia. Compared to this result, the relative expression of MnSOD mRNA in rat brain was increased from day 1 of induced systemic hypoxia and reached its maximum level at day 7 .

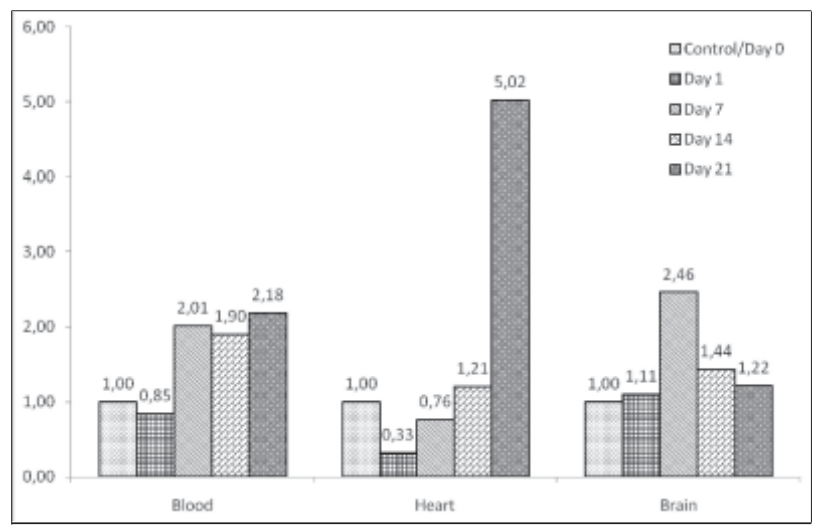

Figure 2. Relative expression level of MnSOD $m R N A$ in rat blood, heart and brain during induced systemic hypoxia. The level of $m R N A$ relative expression of treated groups was determined using Real Time RT-PCR, calculated according to PfaffI formula and normalized to the data of particular control group (as a calibrator with expression level of 1). $\beta$-actin was used as a reference gene.

The result of MnSOD specific activity during early systemic hypoxiawas similar to theresult ofmRNA expression. Figure 3 demonstrates that MnSOD specific activity in rat blood and heart during early systemic hypoxia was significantly (t-test; $\mathrm{p}<.05$ ) decreased on day 1 and subsequently increased afterwards, whereas this activity in rat brain 
was significantly increased from day 1 up to day 14 of systemic hypoxia (t-test; $\mathrm{p}<.01)$. However, under very late hypoxic condition (day 21) the result of MnSOD specific activity in blood, heart and brain was obviously different compared to mRNA expression, since MnSOD activity was decreased, indeed significantly lower in blood and heart as compared to the control group (t-test; $\mathrm{p}<.01$ ).

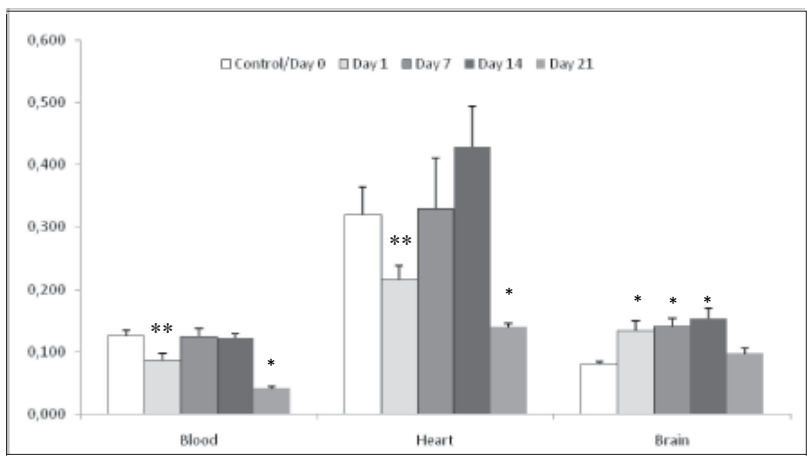

Figure 3. Specific activity of MnSOD in rat blood, heart and brain during induced systemic hypoxia. *: $p<0.01$ vs control group; and **: $p<0.05$ vs control group.

In figure 4, we analyzed the Pearson correlation between mRNA expression and specific activity of MnSOD in these three tissues of systemic hypoxia-induced rats (days 0-21), which have been normalized to the control. The analysis resulted in a negative correlation in rat blood $(r=-0.250)$ and heart $(r=-0.618)$. In contrast to that, a moderate positive correlation was shown in brain $(r=0.528)$. Nevertheless, when we analyzed this correlation in blood and heart of systemic hypoxiainduced rats (days 0-14), we also found a positive correlation in blood $(\mathrm{r}=0.616)$, as well as in heart $(\mathrm{r}=$ 0.943 ). This deviation is due to a drastical decrease of the MnSOD specific activity under very late systemic hypoxic condition (day 21), although the expression of MnSOD mRNA remained increased.

To analyze the correlation of MnSOD mRNA expression and specific activity in heart or brain compared to that in blood, we performed Pearson statistical correlation analysis. We found that there was a positive correlation between the MnSOD mRNA expression in heart and blood $(\mathrm{r}=0.6051)$, as well as in brain and blood $(\mathrm{r}=$ $0.5509)$. The same analysis performed for the MnSOD specific activity resulted in a significant strong correlation between heart and blood $(\mathrm{r}=0.9009)$, but a weak correlation in brain and blood $(\mathrm{r}=0.3167)$.
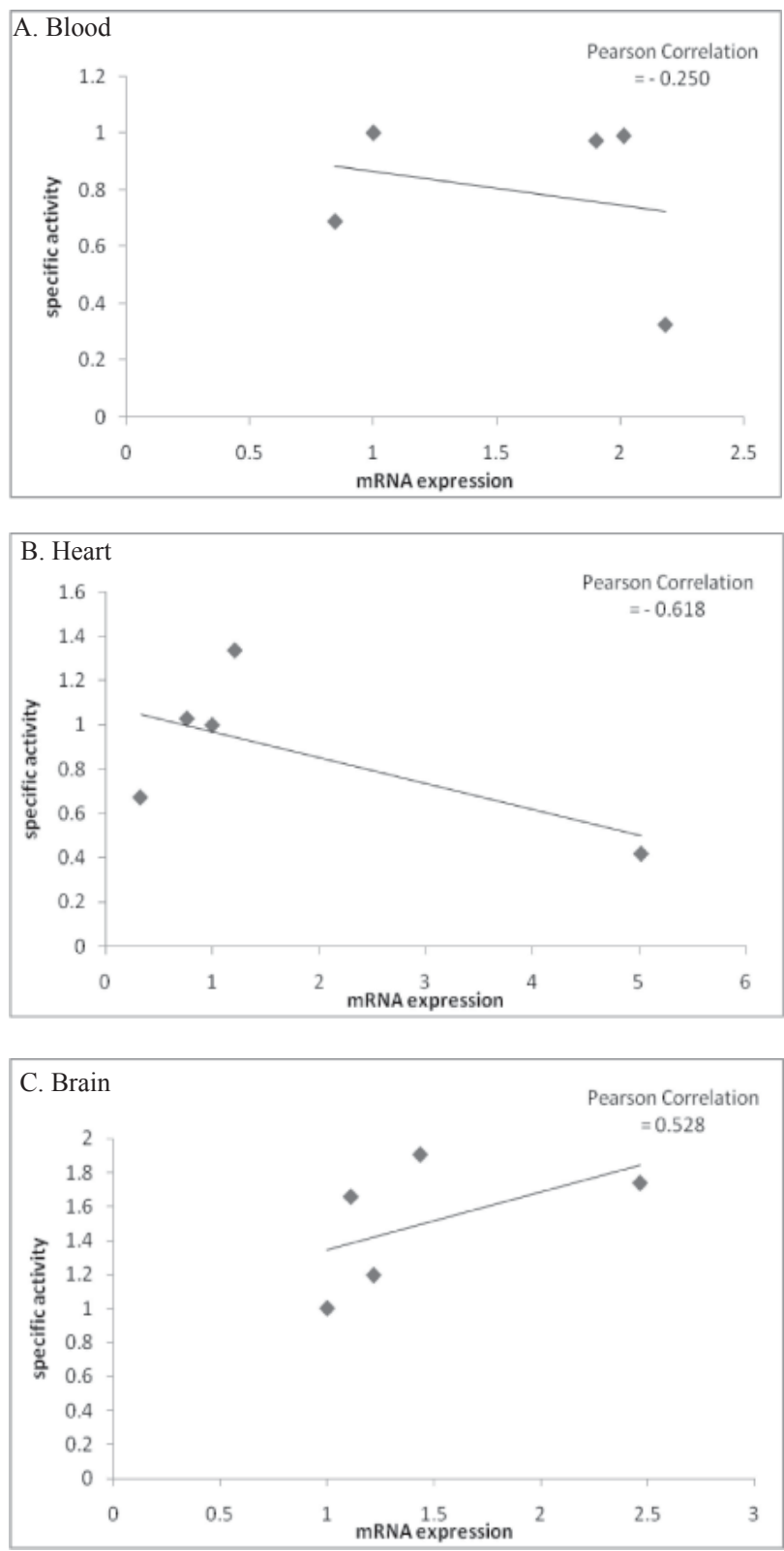

Figure 4. Correlation between $m R N A$ relative expression and specific activity level of MnSOD in rat blood (A), heart $(B)$ and brain $(C)$ during induced systemic hypoxia. MnSOD mRNA expression and activity level of treated groups was normalized to its control.

\section{DISCUSSION}

In this study, exposure to normobaric systemic hypoxia induced profound changes in blood oxygen transport characteristics such as decreased $\mathrm{p}_{\mathrm{a}} \mathrm{O}_{2}$, haematocrit and haemoglobin values (data not shown). These changes are a well-known consequence of increased hypoxiainduced erythropoietin production. ${ }^{14}$ 
Our parallel study using the same animal model and tissue samples reported that the expression of HIF$1 \alpha$ as the oxygen sensor in hypoxic condition has distinct capacity and sensitivity in blood, heart and brain due to the need of oxygen homeostasis in these particular tissues. ${ }^{15}$ Other previous studies in our group also demonstrated that induction of systemic hypoxia increased the expression of HIF-1 $\alpha$ in rat liver tissue during the early phase and subsequently decreased HIF-1 $\alpha$ expression as hypoxia continued. ${ }^{16}$

The analysis of MnSOD mRNA expression in rat blood and heart during induced systemic hypoxia resulted in a similar pattern, indicating that the synthesis of MnSOD in both tissues is similarly regulated. Moreover, this finding is supported by the result of MnSOD specific activity, which demonstrates that both values exert significantly lower levels in the early phase of systemic hypoxia as compared to the control group. This indicates that under early systemic hypoxia (day 1), MnSOD mRNA synthesis in blood and heart was down-regulated, which might be due to the sudden accumulation of ROS. Thus, the cells could not provide enough MnSOD through gene expression to eliminate ROS. Signal transduction pathway for this response is not yet understood and still under our investigation.

Surprisingly, this phenomenon was not found in the brain. Obviously, the brain has a different pattern of MnSOD specific activity compared to blood and heart during the time course of hypoxic induction, particularly in the early stage. We assume that the MnSOD adaptation response in brain in the early phase of systemic hypoxia is more sensitive than in blood and heart suggesting that the brain is less affected by induced systemic hypoxia. Moreover, in contrast to other tissues, brain has an auto-regulation mechanism under low oxygen level condition, such as vasodilatation in order to achieve better oxygen supply. ${ }^{17}$ This mechanism leads to less severe hypoxia and less ROS production than in other tissues. Consequently, also MnSOD response in brain although more sensitive to hypoxia - was generally less expressed than in heart and blood.

The MnSOD response in brain during induced systemic hypoxia correlates well with the HIF-1 $\alpha$ adaptation response. As reported in our parallel study, the increase of HIF-1 $\alpha$ expression in brain was not as obvious as compared to that in heart and blood. This might be due to the low level of ROS in brain. ${ }^{8,15}$ Taking these results together, we can suggest that the adaptation response to systemic hypoxia in brain is differs from that in heart and blood.
The increase of MnSOD activity seems to be one of the cells' adaptive responses - instead of HIF-1 $\alpha$ stabilization - through antioxidant protection against the accumulation of ROS during induced systemic hypoxia. Indeed, it has been reported that MnSOD could modulate HIF-1 $\alpha$ induction through superoxide anion radical. ${ }^{18,19}$ This data was supported by another study demonstrating that overstimulation of the expression of catalase and gluthatione peroxidise could decrease HIF-1 $\alpha$ stabilization during hypoxia. ${ }^{20}$

One should also note that MnSOD activity was decreased in blood, heart as well as brain under very late hypoxic condition (day 21). This indicates that the capacity of MnSOD to eliminate accumulated ROS had become saturated (as found in brain) or in fact reduced to lower levels than in normoxia (as found in blood and heart). Previous study has reported that hypoxia could stimulate ROS production in the mitochondria and regulate transcription and post-transcription responses against low level of oxygen. ${ }^{21}$ Russel et al. reported that MnSOD activity in the lungs of mice was significantly decreased under hypoxic condition, whereas its mRNA expression was not different from control. ${ }^{22}$ Furthermore, under very late hypoxic condition ATP production is reduced leading to the inhibition of protein translation even though mRNA expression increases. The inhibition of protein translation during hypoxia appears to be an effort of cells to reduce energy consumption in order to maintain the energy balance. However, this inhibition was shown to be still reversible. ${ }^{23}$

In hypoxic condition, MnSOD gene expression might be regulated by redox-sensitive transcription factors, such as SP-1, AP-1 and NF- $\kappa$ B. ${ }^{3}$ Ohman et al. have demonstrated that the increase of ROS could activate NF- $\kappa B$, hence induce the transcription of regulated genes including MnSOD gene. ${ }^{24}$ This data confirms our suggestion that the MnSOD gene expression during hypoxic condition is regulated through the increase of ROS.

It should also be considered that the levels of MnSOD specific activity in each tissue were distinct although measured under the same condition. This indicates that sensitivity and efficiency of the antioxidant response in brain, heart and blood cells vary depending on the extent of ROS accumulation.

Analysis of correlation between the level of mRNA expression and specific activity of MnSOD during days $0-21$ of systemic hypoxia resulted in an obvious deviation from the correlation during days $0-14$. Changes 
in mRNA expression were parallel to the changes in specific activity of MnSOD in blood, heart and brain during days 0-14 of systemic hypoxia. However, at day $21 \mathrm{MnSOD}$ specific activity decreased drastically, even though mRNA expression increased considerably. This might be due to the production of massive amounts of ROS as an impact of induced systemic hypoxia at the very late stage. The increase of mRNA expression is not sufficient to eliminate the oxidative stress. This suggestion is supported by the decrease of enzyme specific activity, indicating that the capacity of MnSOD for eliminating the accumulated ROS has been saturated.

The positive correlation of MnSOD mRNA expression and specific activity between heart and blood of systemic hypoxic rats is more significant and stronger than the correlation between brain and blood. This indicates that the effect of systemic hypoxia on MnSOD expression in blood could better describe its effect in heart than in brain cells. Therefore, we suggest that determination of MnSOD expression (mRNA and level of specific activity) in blood can be used as a biomarker of its expression in heart. This finding would obviously bring more benefit for clinical application, since the determination of MnSOD expression in human heart under hypoxic condition is still not applicable.

From our results, we conclude that the expression of MnSOD in different tissues as well as at different stages (early and late) of induced systemic hypoxia in rats is distinctly regulated. Brain tissue appears to survive better during induced systemic hypoxia than heart and blood cells, due to earlier antioxidant response through MnSOD activity. Moreover, the determination of MnSOD expression in blood could be used to describe its expression in heart. Further studies are required to elaborate the MnSOD specific activity in other cells during induced systemic hypoxia, as well as to analyze the correlation between MnSOD expression and apoptosis.

\section{Acknowledgments}

This research was funded by Hibah Riset Unggulan Universitas Indonesia (RUUI) 2007. The authors would like to thank Dr. dr. Frans Ferdinal, MS for kindly providing us the hypoxic chamber and to $\mathrm{dr}$. Novi Silvia, MBiomed, dr. Reni Paramita, MBiomed and Ondi Sutisna for excellent technical supports.

\section{REFERENCES}

1. Giaccia AJ, Simon MC, Johnson R. The biology of hypoxia: the role of oxygen sensing in development, normal function, and disease. Gene \& Dev. 2004;18:2183-94.
2. Michiels C. Physiological and pathological responses to hypoxia. Am J Pathol. 2004;164:1875-82.

3. Haddad JJ. Oxygen sensing mechanism and the regulation of redox-responsive transcription factors in development and pathophysiology. Respir Res. 2002;3:1-27.

4. Semenza GL. HIF-1: Mediator of physiological and pathophysiological responses to hypoxia. J Appl Physiol. 2000;88:1474-80

5. Semenza GL. Hydroxylation of HIF-1: oxygen sensing at the molecular level. Physiology. 2004;19:176-82.

6. Lee JW, Bae SH, Jeong JW, Kim SH, Kim KW. Hypoxiainducible factor (HIF-1) $\alpha$ : its protein stability and biological functions. Exp and Mol Med. 2004;36(1):1-12.

7. Halliwell B, Gutteridge JMC. Free radicals in biology and medicine. $4^{\text {th }}$ ed. London: Oxford University Press; 2007.

8. Chandel NS, Maltepe E, Goldwasser E, Mathieu CE, Simon MC, Schumacker PT. Mitochondrial reactive oxygen species trigger hypoxia-induced transcription. Proc Natl Acad Sci USA. 1998;95:11715-20.

9. Lebovitz RM, Zhang H, Vogel H, Cartwright J, Dionne $\mathrm{L}, \mathrm{Lu} \mathrm{N}$ et al. Neurodegeneration, myocardial injury and perinatal death in mitochondrial SOD-deficient mice. Proc Natl Acad Sci USA. 1996;93:9782-87.

10. Skrzycki M, Czeczot H. Superoxide dismutase as a potential therapeutic agent. Adv Clin Exp Med. 2007;16(4):561-8.

11. Martin RCG, Barker DF, Doll MA, Pine SR, Mechanic L, Bowman ED, et al. Manganese superoxide dismutase gene coding region polymorphisms lack clinical incidence in general population. DNA and Cell Biol. 2008;27(6):321-3.

12. Corno AF, Milano G, Samaja M, Tozzi P, von Segesser LK. Chronic hypoxia: a model for cyanotic congenital heart defects. J Thorac Cardiovasc Surg 2002;124:105-12.

13. Hardiany NS, Sadikin M, Wanandi SI. Gene expression of manganese superoxide dismutase in human glioma cells. Med J Indones. 2010;19:21-5.

14. Ferdinal F. Mekanisme molekuler gagal jantung yang diinduksi hipoksia: Peran HIF-1 $\alpha$ dalam regulasi gen B-type natriuretic peptide-45 [dissertation]. Doctoral Program in Biomedical Sciences: Faculty of Medicine University of Indonesia; 2009.

15. Wanandi SI, Paramita R, Syarifah D. Relative Expression of HIF-1 $\alpha$ mRNA in Rat Heart, Brain and Blood During Induced Systemic Hypoxia. Makara Seri Sains. 2009;13(2):185-8.

16. Jusman SWA, Sadikin AH, Wanandi SI, Sadikin M. Expression of Hypoxia-inducible Factor-1 $\alpha$ (HIF-1 $\alpha$ ) related to oxidative stress in liver of rat-induced by systemic chronic normobaric hypoxia. Acta Medica Indones-Indones J Intern Med. 2010;42(1):17-23.

17. Tortora GJ, Derrickson B. Principles of Anatomy and Physiology. 12 ${ }^{\text {th }}$ ed. Hoboken: John Wiley \& Sons Inc., 2009.

18. Wang M, et al. Manganese superoxide dismutase suppresses hypoxic induction of hypoxia-inducible factor- $1 \alpha$ and vascular endothelial growth factor. Oncogene. 2005;24:8154-66.

19. Kaewpila S, Venkataraman S, Buettner GR and Oberley LW. Manganese Superoxide Dismutase Modulates HypoxiaInducible Factor- $1 \alpha$ Induction via Superoxide. Cancer Res. 2008;68(8):2781-8.

20. Brunelle JK, Bell EL, Quesada NM, Vercauteren K, Tiranti $\mathrm{V}$, Zeviani $\mathrm{M}$, et al. Oxygen sensing requires mitochondrial 
ROS but not oxidative phosphorylation. Cell Metabol. 2005;1:409-14.

21. Schumacker PT. Current paradigms in cellular oxygen sensing. Adv Exp Med Biol. 2003;543:57-71.

22. Russel WJ, Ho YS, Jackson RM. Effects of hypoxia on MnSOD expression in mouse lung. Am J Physiol. 1995;2(1):221-6.

23. Koumenis C, Naczki C, Koritzinsky M, Rastani S, Diehl A, Sonenberg N, et al. Regulation of protein synthesis by hypoxia via activation of the endoplasmic reticulum kinase PERK and phosphorylation of the translation initiation factor eIF2alpha. Mol Cell Biol. 2002;22:7405-16.

24. Ohman T, Parish G, Jackson RM. Hypoxic modulation of manganese superoxide dismutase promoter activity and gene expression in lung epithelial cells. Am J Respir Cell Mol Biol. 1999;21:119-27. 